Gut, 1961, 2. 285

\title{
Long-term medical management and complications of 'resistant' ascites
}

\author{
WILLIAM H. J. SUMMERSKILL, BERNARD F. CLOWDUS, II, ${ }^{1}$ \\ AND JOHN W. ROSEVEAR \\ From the Mayo Clinic and Mayo Foundation, Rochester, Minnesota
}

SYNOPSIS This paper reports the experience of treating patients with hepatic cirrhosis and ascites with an aldosterone inhibitor in addition to conventional therapy. Good results are demonstrated in 13 patients previously resistant to treatment.

Ratnoff and Patek (1942) commented that ascites was the most frequent and characteristic sign of hepatic cirrhosis, and the serious prognosis of this complication was evident from the six-month survival of only $50 \%$ of their patients. Despite progress in therapy, the outlook remains extremely grave when the onset of ascites is insidious and when resistance develops to treatment with sodium restriction and standard diuretic agents (Sherlock, 1958). Most authorities agree with Blakemore (1952) that intractable ascites represents an end stage of cirrhosis and that such patients have at best but a few months to live. Available measures include paracentesis abdominis, a temporary expedient which may lead to protein and electrolyte depletion, hypotension, and coma (Sherlock, 19j8), or various portal-systemic shunt operations (Blakemcre, 1952; Linton, 1956; McDermott, 1960). The last reduce portal pressure and obstruction to hepatic venous or lymphatic flow but affect only mechanical aspects of the disease. Operative mortality with resistant ascites may exceed $40 \%$ (Linton, 1956), while the subsequent development of progressive hepatic failure or neuropsychiatric changes are also important considerations. Refractory ascites, therefore, is considered a strong contraindication to the surgical treatment of portal hypertension (Sherlock, 1958; Blakemore, 1952; Mackby, 1960; Walker, 1957), although newer techniques may justify some reappraisal (McDermott, 1960).

Since patients with cirrhosis and ascites have features of excess aldosterone activity (Luetscher and Johnson, 1954), the management of refractory

\footnotetext{
'On assignment to the Mayo Foundation. The contents of this article are the personal views of the authors and are not to be construed as official Air Force policy nor as Air Force endorsement of any commercial product described.
}

fluid retention has been directed toward methods of combating hyperaldosteronism. Bilateral adrenalectomy (Marson, 1954; Giuseffi, Werk, Larson, Shiff, and Elliott, 1957) has been effective only occasionally, presumably because of the dangers of the procedure in patients with liver disease and the difficulties involved in immediate and long-term postoperative management. Medical suppression of adrenocortical function has been attempted (Summerskill and Crabbé, 1957; Stormont, Crabbé, Fast, Wolfe, and Davidson, 1959) but the toxicity of the drugs available precludes their long-term use. More recently, steroidal lactones (Kagawa, Cella, and van Arman, 1957), which act as chemical antagonists of aldosterone (Liddle, 1958), have been given by mouth without side-effects to patients with cirrhosis and have procured an initial diuresis, even when the ascites was refractory to standard measures (Clowdus, Higgins, Rosevear, and Summerskill, 1960; Henley, Streeten, and Pollard, 1960).

The progress of patients with resistant ascites treated medically is rarely specified after they leave the hospital and depends on many factors associated with hepatic disease, but particularly on their ability to adhere to a strict regimen of diet and drugs. In this paper, details of an effective long-term medical regimen to control ascites previously resistant to medical management by using an aldosterone antagonist in combination with standard diuretics are described, and the progress of 13 patients thus treated for periods up to two years is reported. Special attention is given to relaxation of the dietary restriction of sodium, which is made possible with treatment, to the influence of liver function in determining prognosis, and to the nature and management of complications arising during treatment. 


\section{MATERIALS AND METHODS}

Thirteen patients with cirrhosis (Table l) were treated at first in a hospital and were examined subsequently at intervals of two weeks to three months throughout the period of follow-up. The diagnosis of cirrhosis was made on clinical grounds, being supported by biochemical tests of liver function (Table I) and, in eight instances, by histological examination of hepatic tissue. Six patients (Cases 4, 5, 8, 9, 11, and 13) had been chronic alcoholics, but continued alcoholism had been a factor during the preceding two months in only one (Case 13). In the other patients, the cause of the cirrhosis and its possible relationship to previous hepatitis was uncertain (cryptogenic). Tense ascites had been present for periods of one month to three years despite treatment and was shown to be refractory for 10 days or longer to treatment with dietary restriction of sodium (less than $10 \mathrm{mEq}$. in 24 hours), and combinations of meralluride (mercuhydrin), chlorothiazide, or prednisone in the hospital. Nine patients had required paracenteses on two to 12 occasions during the preceding year, and

TABLE I

PATIENTS STUDIED AND RESULTS OF TREATMENT

\begin{tabular}{|c|c|c|c|c|c|c|c|c|c|c|c|c|c|}
\hline \multirow[b]{2}{*}{ రัँ } & \multirow[b]{2}{*}{ 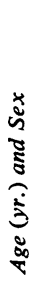 } & & \multirow{2}{*}{ 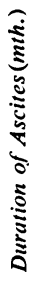 } & \multicolumn{3}{|c|}{ Previous History ${ }^{1}$} & \multicolumn{2}{|c|}{$\begin{array}{l}\text { Loss of Weight } \\
\text { in Hospital with } \\
\text { Initial Treatment }\end{array}$} & \multicolumn{4}{|c|}{$\begin{array}{l}\text { Chemical Tests of Liver Function } \\
\text { (a) Initial and (b) Latest Follow-up }\end{array}$} & \multirow[t]{2}{*}{ Comments } \\
\hline & & & & 芯 & 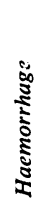 & 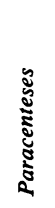 & 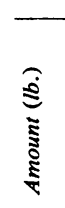 & 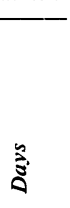 & 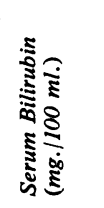 & 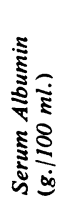 & 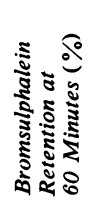 & 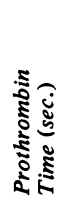 & \\
\hline $1^{2}$ & 55 & $\mathrm{~F}$ & 32 & 1 & 0 & 3 & 35 & 70 & $\begin{array}{l}\text { (a) } 1.9 \\
\text { (b) } 1.3\end{array}$ & $\begin{array}{l}3 \cdot 0 \\
3 \cdot 4\end{array}$ & $\begin{array}{l}>30 \\
>30\end{array}$ & $\begin{array}{l}23 \\
24\end{array}$ & $\begin{array}{l}\text { Transient impending coma with } \\
\text { chlorothiazide, otherwise well } \\
\text { for } 24 \text { mth., taking diuretics } \\
\text { daily and } 80 \text {-mEq. sodium diet } \\
\text { (see Fig. 2) }\end{array}$ \\
\hline $2^{2}$ & 67 & $\mathbf{F}$ & 18 & 0 & 0 & 3 & 8 & 22 & $\begin{array}{l}\text { (a) } 1 \cdot 1 \\
\text { (b) } 1.0\end{array}$ & $\begin{array}{l}2 \cdot 4 \\
3 \cdot 8\end{array}$ & $\begin{array}{l}>30 \\
>30\end{array}$ & $\begin{array}{l}22 \\
23\end{array}$ & $\begin{array}{l}\text { Died after } 2 \mathrm{mth} \text {. Azotaemia } \\
\text { and terminal gastrointestinal } \\
\text { haemorrhage }\end{array}$ \\
\hline $3^{2}$ & 51 & $\mathbf{M}$ & 9 & 0 & 0 & 2 & 23 & 18 & $\begin{array}{l}\text { (a) } 2 \cdot 6 \\
\text { (b) } 3 \cdot 3\end{array}$ & $\begin{array}{l}3 \cdot 0 \\
3 \cdot 2\end{array}$ & $\begin{array}{l}>30 \\
>40\end{array}$ & $\begin{array}{l}22 \\
23\end{array}$ & $\begin{array}{l}\text { Well for } 22 \text { mth., taking } \\
\text { intermittent diuretic therapy } \\
\text { and } 10 \text {-mEq. sodium diet }\end{array}$ \\
\hline 4 & 46 & $\mathbf{M}$ & 6 & 1 & 0 & 0 & 12 & 22 & $\begin{array}{l}\text { (a) } 1.4 \\
\text { (b) } 0.7\end{array}$ & $\begin{array}{l}4 \cdot 2 \\
4 \cdot 7\end{array}$ & $\begin{array}{r}>30 \\
16\end{array}$ & $\begin{array}{l}22 \\
18\end{array}$ & $\begin{array}{l}\text { Well for } 15 \mathrm{mth} \text {. Transient } \\
\text { hyponatraemia and azotaemia, } \\
\text { slow improvement in hepatic } \\
\text { function, no therapy necessary }\end{array}$ \\
\hline $5^{2}$ & 59 & $\mathbf{M}$ & 36 & 0 & 3 & 24 & 14 & 22 & $\begin{array}{l}\text { (a) } 1.2 \\
\text { (b) } 0.7\end{array}$ & $\begin{array}{l}3 \cdot 4 \\
4 \cdot 8\end{array}$ & $\begin{array}{l}20 \\
20\end{array}$ & $\begin{array}{l}21 \\
19\end{array}$ & $\begin{array}{l}\text { Well for } 20 \text { mth., taking } \\
\text { intermittent diuretic therapy and } \\
10 \text {-mEq. sodium diet }\end{array}$ \\
\hline $6^{2}$ & 69 & $\mathbf{M}$ & 3 & 0 & 0 & 0 & 65 & 32 & $\begin{array}{l}\text { (a) } 1.4 \\
\text { (b) } 1.2\end{array}$ & $\begin{array}{l}3 \cdot 8 \\
4 \cdot 0\end{array}$ & $\begin{array}{l}30 \\
30\end{array}$ & 24 & $\begin{array}{l}\text { Died after } 6 \text { mth. Hepatoma } \\
\text { invading portal vein with re- } \\
\text { accumulation of ascites and } \\
\text { terminal gastrointestinal } \\
\text { haemorrhage }\end{array}$ \\
\hline 7 & 61 & $\mathbf{M}$ & 2 & 1 & 0 & 1 & 32 & 30 & $\begin{array}{l}\text { (a) } 2 \cdot 3 \\
\text { (b) } 2 \cdot 1\end{array}$ & $\begin{array}{l}2 \cdot 4 \\
2 \cdot 6\end{array}$ & $\begin{array}{l}30 \\
30\end{array}$ & $\begin{array}{l}22 \\
19\end{array}$ & $\begin{array}{l}\text { Died of unrelated cause after } \\
2 \mathrm{mth} \text {. }\end{array}$ \\
\hline $8^{2}$ & 61 & $\mathbf{M}$ & 1 & $\mathbf{0}$ & - & - & 33 & 20 & $\begin{array}{l}\text { (a) } 4 \cdot 1 \\
\text { (b) } 5 \cdot 9\end{array}$ & $\begin{array}{l}2 \cdot 7 \\
2 \cdot 8\end{array}$ & - & 21 & $\begin{array}{l}\text { Died after } 1 \mathrm{mth} \text {. from } \\
\text { gastrointestinal haemorrhage. } \\
\text { Hepatoma found at necropsy }\end{array}$ \\
\hline $9^{2}$ & 64 & $\mathbf{F}$ & 12 & 1 & 0 & 5 & 16 & 11 & $\begin{array}{l}\text { (a) } 1.2 \\
\text { (b) } 0.9\end{array}$ & $\begin{array}{l}3 \cdot 7 \\
3 \cdot 7\end{array}$ & $\begin{array}{l}>\mathbf{3 0} \\
>\mathbf{3 0}\end{array}$ & 20 & $\begin{array}{l}\text { Well for } 9 \mathrm{mth} \text {., taking diuretics } \\
\text { and } 40-80-\mathrm{mEq} \text {. sodium diet. } \\
\text { Died in hepatic failure with } \\
\text { azotaemia }\end{array}$ \\
\hline $10^{2}$ & 44 & $\mathbf{M}$ & 24 & 1 & 0 & 4 & 22 & 19 & $\begin{array}{l}\text { (a) } 0.9 \\
\text { (b) } 1.1\end{array}$ & $\begin{array}{l}3 \cdot 2 \\
3 \cdot 4\end{array}$ & $\begin{array}{l}>30 \\
>30\end{array}$ & $\begin{array}{l}20 \\
21\end{array}$ & $\begin{array}{l}\text { Died after } 4 \mathrm{mth} .: \text { azotaemia } \\
\text { and hyperkalaemia (Fig. 4) }\end{array}$ \\
\hline 11 & 40 & $\mathbf{F}$ & 24 & $\mathbf{0}$ & 0 & 1 & 17 & 24 & $\begin{array}{l}\text { (a) } 2.5 \\
\text { (b) } 0.6\end{array}$ & $\begin{array}{l}2 \cdot 8 \\
5 \cdot 0\end{array}$ & $\begin{array}{r}>30 \\
16\end{array}$ & $\begin{array}{l}22 \\
18\end{array}$ & $\begin{array}{l}\text { Well for } 15 \mathrm{mth} \text {. Slow improve- } \\
\text { ment in liver function. No } \\
\text { therapy now necessary }\end{array}$ \\
\hline $12^{2}$ & 62 & $\mathbf{F}$ & 7 & 1 & 0 & 6 & 23 & 24 & $\begin{array}{l}\text { (a) } 3.6 \\
\text { (b) } 5.3\end{array}$ & $\begin{array}{l}2 \cdot 7 \\
2 \cdot 4\end{array}$ & $>30$ & $\begin{array}{l}20 \\
21\end{array}$ & $\begin{array}{l}\text { Died after } 3 \text { mth.: azotaemia } \\
\text { and terminal gastrointestinal } \\
\text { haemorrhage }\end{array}$ \\
\hline $13^{2}$ & 49 & $\mathbf{M}$ & 1 & $\mathbf{0}$ & 0 & $\mathbf{0}$ & 51 & 32 & $\begin{array}{l}\text { (a) } 9.2 \\
\text { (b) } 1.50\end{array}$ & $\begin{array}{l}2.8 \\
3.9\end{array}$ & $\overline{22}$ & $\begin{array}{l}27 \\
22\end{array}$ & $\begin{array}{l}\text { Well for } 9 \text { mth., taking } \\
\text { 20-mEq. sodium diet. } \\
\text { Recovered from gastrointestinal } \\
\text { haemorrhage and azotaemia }\end{array}$ \\
\hline
\end{tabular}

'All had been unresponsive to diet and diuretics previously 'Patients with gastro-oesophageal varices 
10 had splenomegaly with oesophageal varices as evidence of portal hypertension. Post-mortem examinations were made on all patients who died.

During initial hospital treatment patients were given diets containing on analysis less than $10 \mathrm{mEq}$. of sodium and between 80 and $100 \mathrm{mEq}$. of potassium daily. Fluid intake was restricted only if azotaemia occurred. Weight was determined daily, and the volume, together with the sodium and potassium contents, of 278 specimens of 24-hour urine was determined during the treatment of patients 1 to 9 . During the time in hospital and at follow-up appointments, chemical tests of liver function and concentrations of blood urea, together with serum sodium, potassium chloride, and bicarbonate, were measured at intervals by standard procedures. Determinations of ammonia in arterial blood using the method of Seligson and Hirahara (1957), and electroencephalographic recordings, which were graded 0 to 4 (Summerskill, Clowdus, and Casey, 1960a), were made on patients with neuropsychiatric changes. Exchangeable sodium, exchangeable potassium, and total body water were measured by using $\mathrm{Na}^{24}, \mathrm{~K}^{42}$, and $\mathrm{D}_{2} \mathrm{O}$ as tracer substances, as described elsewhere (Summerskill et al., 1960a; Clowdus, II, Summerskill, Casey, Higgins, and Orvis, 1961).

\section{PRELIMINARY ASSESSMENT AND RESPONSE TO INITIAL TREATMENT}

Initially, all patients had evidence of severe hepatic disease with ascites and muscle wasting (Table I).
Three patients were clinically jaundiced, one being deeply icteric. All had direct-reacting bilirubin in the serum. The concentration of serum albumin initially was $3 \mathrm{~g}$. per $100 \mathrm{ml}$. or less in eight patients, and all who were not jaundiced had grossly abnormal retention of sulphobromophthalein (bromsulphalein). Serum glutamic oxalacetic transaminase activity and concentrations of globulin were abnormal in every instance. All patients were hypoprothrombinaemic, and the prothrombin time was unresponsive to treatment with vitamin K. Five patients (Cases 4, $7,9,10$, and 13) had initial clinical and electroencephalographic evidence of impending hepatic coma, and two (Cases 1 and 10) had previously had coma following paracentesis. These considerations were felt to preclude any patient from consideration for surgical treatment.

After resistance of the ascites to a low-sodium diet with standard diuretic agents (mercuhydrin, chlorothiazide, and prednisone) had been confirmed, each patient was given medication with spirolactonealdactone, 400 to $1,200 \mathrm{mg}$. in two to four doses daily in combination with chlorothiazide, 500 to $1,000 \mathrm{mg}$. in two doses daily; meralluride (mercuhydrin), $2 \mathrm{ml}$. daily intramuscularly; or prednisone, $30 \mathrm{mg}$. daily in three doses (Fig. 1). Adjustments of the dose and frequency of administration of each drug and of the most satisfactory combinations of

Mean 24 hour weight change (Ib.)

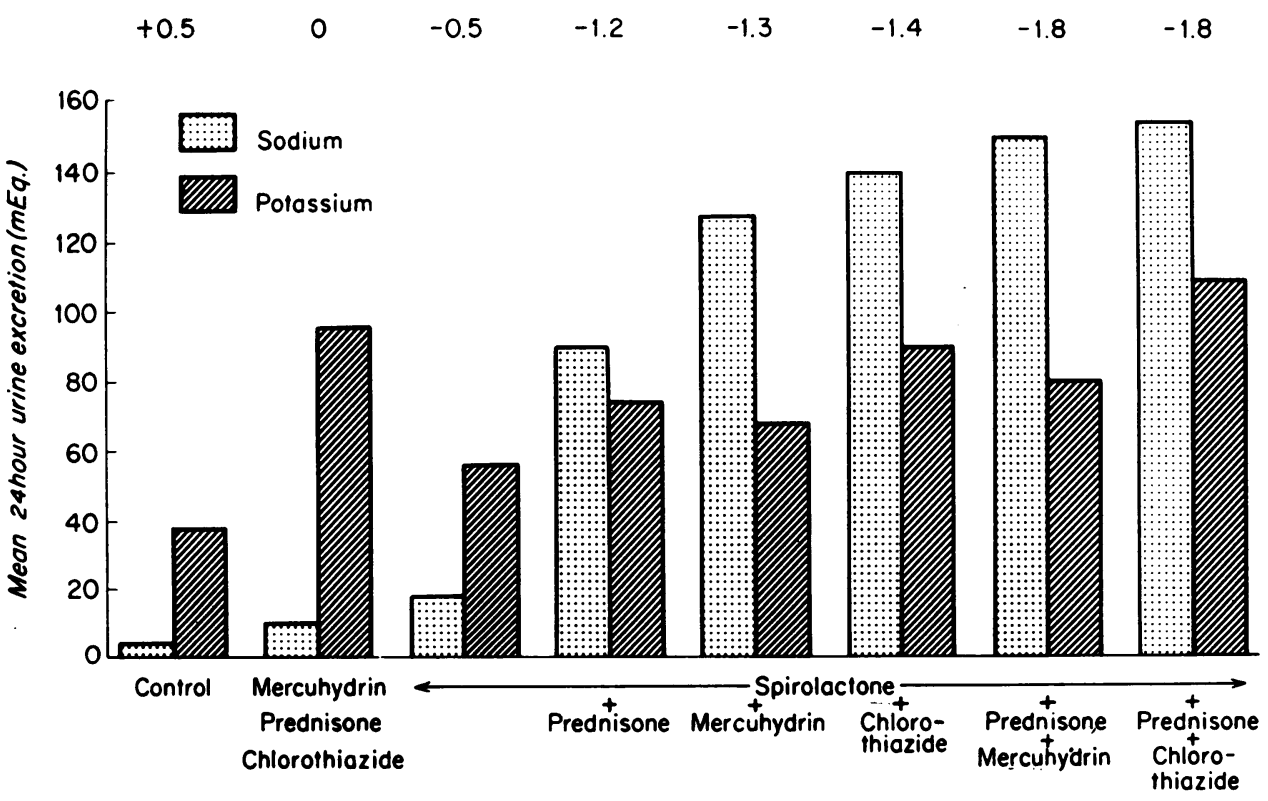

FIG. 1. Mean change in weight, volume of urine, and urinary excretion of sodium and potassium in relation to treatment. 
drugs to produce a sustained diuresis were necessary in each patient.

All responded strikingly to treatment (Table I and Fig. 1), between 8 and $65 \mathrm{lb}$. in weight being lost in 12 to 42 days. The greatest loss of weight by an individual in 24 hours was $5 \frac{1}{2} \mathrm{lb}$., this being associated with a 24-hour excretion of $337 \mathrm{mEq}$. or sodium. There was usually a delay of a week, and sometimes considerably longer, before the diuresis began. With aldactone alone, a moderately increased amount of sodium was excreted in association with trivial loss of weight. The addition of prednisone or aldactone doubled loss of weight and increased excretion of sodium more than fourfold, while the use of aldactone in combination with chlorothiazide or mercuhydrin promoted comparable loss in weight but greater excretion of sodium. Two drugs were more effective than one in combination with aldactone; greater loss of weight and excretion of sodium occurred when either mercuhydrin or chlorothiazide was added to aldactone and prednisone. The greatest loss of weight (water) in relation to urinary excretion of sodium and potassium occurred when prednisone was administered with aldactone; the addition of thiomerin or chlorothiazdie to this combination of drugs caused a proportionately greater increase in excretion of the cations than loss of weight. Loss of potassium was greatest during regimens in which chlorothiazide was incorporated, and least when aldactone was administered. When aldactone and chlorothiazide were given together, a negative potassium balance often occurred.

Apart from improvement in jaundice in patient 13, there was no significant change in hepatic function tests during the period of initial diuresis. However, four of five patients who initially were in impending hepatic coma recovered during treatment, which included chlorothiazide, without antibiotic therapy or restriction of protein. No neuropsychiatric changes developed in the other patients. Complications arising during initial treatment, including those involving water and electrolyte metabolism, are discussed later.

\section{RESULTS OF LONG-TERM MANAGEMENT}

Long-term programmes of management after the patients left the hospital were adjusted to subsequent progress determined by their ability to continue a diet severely restricted in sodium and to abstain from alcohol, as well as by alterations in hepatic function and other complications incident to liver disease. Six patients (Cases 1, 3, 4, 5, 11, and 13) are alive and have remained free from significant fluid accumulation during periods of eight months to two years (mean 16 months). One patient (Case 7) died at home of an unrelated cause without reaccumulating ascites. Six patients died as a result of complications due to progressive liver disease and portal hypertension (Table I). The mean survival period in these cases was only four months, but gross ascites re-accumulated in only one (Case 6), this being due to occlusion of the portal vein by hepatoma.

Two patterns of response were defined during follow-up studies: (1) that of the patients who ultimately dispensed with diet and drugs, and (2) that of the patients who required continuous therapy. The second group of patients was subdivided into those who were able to continue strict sodium restriction at home (as shown by analysis of aliquots of their diets) and those in whom some relaxation of sodium intake was inevitable because of their inability to prepare or adhere to a correct diet. A trivial amount of ascites was allowed to accumulate in patients taking diuretics continuously as a precaution against sodium depletion.

PATIENTS RETURNING TO NORMAL DIETS WITHOUT DIURETIC THERAPY Three patients (Cases 4, 11, and 13) were chronic alcoholics in whom ascites had developed within the year preceding treatment but who ceased drinking one to three months before entering the hospital. After initial treatment, liver function improved in patient 13 only. All avoided further consumption of alcohol, and a diet providing approximately $10 \mathrm{mEq}$. of sodium, a liberal intake of protein (through low-sodium supplements), and added vitamins was prescribed. Subsequently, none reaccumulated fluid, all gained flesh, and hepatomegaly decreased. Chemical tests of liver function improved commensurately (Table I). The daily sodium content of the diet was increased cautiously by $20 \mathrm{mEq}$. increments at three-monthly intervals, and all have now reverted to normal diets without adverse effects, nine to 18 months having elapsed without retention of fluid.

PATIENTS REQUIRING CONTINUOUS TREATMENT The patients in this group can be subdivided into two groups according to whether they required intermittent or continuous diuretic therapy.

1 Dietary Sodium of $10 \mathrm{mEq}$. Daily with Intermittent Diuretic Therapy Two patients (Cases 3 and 5) were free from ascites when they left the hospital, and continued a diet providing approximately $10 \mathrm{mEq}$. of sodium without undue difficulty. Subsequently, fluid re-accumulated, with gains of 4 and $6 \mathrm{lb}$. within three months, and in addition to diet diuretics were necessary. After several adjustments, one patient (Case 3) has remained 

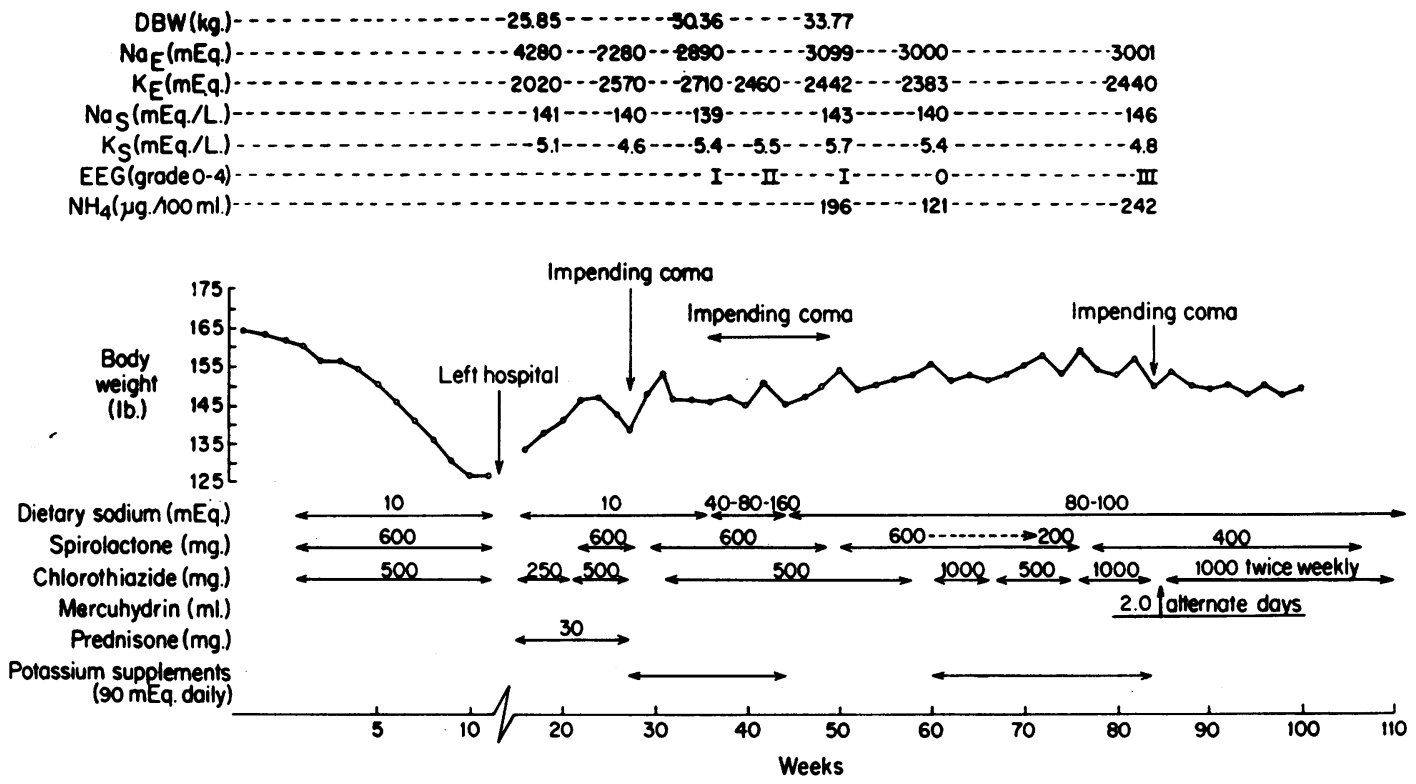

FIG. 2. Details of treatment and complications in the long-term management of resistant ascites (patient 1). Diet and medication are related to body weight, dry body weight $(D B W)$, exchangeable sodium $\left(N a_{E}\right)$ and potassium $\left(K_{E}\right)$ values; serium sodium $\left(\mathrm{Na} \mathrm{a}_{S}\right)$ and potassium $\left(\mathrm{K}_{S}\right)$ concentrations, and arterial ammonia concentrations $\left(\mathrm{NH}_{4}\right)$.

free from ascites for 22 months with treatment for one week every two months with spirolactone, $600 \mathrm{mg}$. daily, to which prednisone, $30 \mathrm{mg}$. daily, and chlorothiazide, $500 \mathrm{mg}$. twice daily, has been added during the last three days of the week. Patient 5 has again become responsive to chlorothiazide and has maintained a steady weight for 19 months by taking $500 \mathrm{mg}$. of this drug on alternate days. On similar regimens, patient 7 remained free from significant ascites until his death, but patient 6 re-accumulated fluid at home terminally.

2 Liberal Dietary Sodium with Continuous Diuretic Therapy Five patients (Cases 1, 8, 9, 10, and 12) were unable technically or by inclination to persevere with strict dietary restriction of sodium. Consequently, fluid began to re-accumulate after discharge from the hospital. Studies of sodium balance (Clowdus et al., 1960) showed that the daily administration of spirolactone in doses of 300 to $800 \mathrm{mg}$., together with other diuretics, permitted relaxation of the dietary restriction of sodium without undue retention or loss of sodium. Careful supervision with frequent readjustments of treatment was necessary, but with appropriate regimens all remained free from obvious ascites, despite diets containing 50 to $100 \mathrm{mEq}$. of sodium. Management sometimes involved difficulties, most of which are illustrated by the progress of patient 1 (Fig. 2).
After a good response to treatment in hospital and stabilization of weight on diet alone, this patient was unable to persevere with the diet at home and gained $7 \mathrm{lb}$. within six weeks. Chlorothiazide, prednisone and then spirolactone were prescribed in varying doses. She then lost weight, but an episode of impending coma, presumed to be due to chlorothiazide, necessitated withdrawal of drugs. Weight again increased; a return to treatment with aldactone and chlorothiazide was made with satisfactory diuresis, potassium supplements having been added to the regimen. However, an intermittent mild neuropsychiatric disorder persisted with minor abnormalities in the electroencephalogram.

An attempt was then made to provide more sodium in the diet. Balance studies with an $80-\mathrm{mEq}$. sodium diet showed a satisfactory sodium balance and no gain in weight, while treatment with diuretics was continued, but fluid accumulated with greater amounts of sodium. Accordingly, an $80-\mathrm{mEq}$. sodium diet with continued daily treatment with spirolactone and chlorothiazide was instituted satisfactorily. Attempts to stop chlorothiazide and later to reduce the dosage of aldactone slowly by $100 \mathrm{mg}$. were followed by increases in weight. Diuresis was procured by increasing the dose of chlorothiazide, but another transient episode of impending coma occurred. The dose of spirolactone was increased, but replacement of chlorothiazide by 
injections of thiomerin on alternate days failed to retard the gain in weight. With a schedule of spirolactone, $400 \mathrm{mg}$. daily, with chlorothiazide given only twice weekly in doses of $500 \mathrm{mg}$. twice a day, the subsequent course has been satisfactory. Thus a palatable diet requiring little special preparation has been combined satisfactorily with continuous diuretic therapy which is less likely to cause complications.

Certain observations, which apply also to other patients, were evident from this study. A considerable proportion of the weight gained after leaving the hospital was due to increase in flesh, as shown by serial calculations of the dry body weight (DBW), which represents body weight less body water. Neuropsychiatric complications occurred specifically in relation to chlorothiazide therapy, but could not be related to potassium depletion, as values for exchangeable body potassium $\left(\mathrm{K}_{E}\right)$, $\mathrm{K}_{E} / \mathrm{DBW}(78 \cdot 1,89 \cdot 2$ and $72 \cdot 3 \mathrm{mEq} . / \mathrm{kg}$.), and concentrations of serum potassium $\left(\mathrm{K}_{S}\right)$ were not strikingly changed in the presence of clinical or electroencephalographic evidence of impending coma. Moreover, potassium supplements failed to protect against the onset of coma on two occasions and were not followed by striking increases in body potassium stores as shown by $\mathrm{K}_{E}$ measurements. In contrast, concentrations of ammonia in arterial blood were above the normal range (less than 100 mcg. per $100 \mathrm{ml}$.) and became more abnormal in association with the clinical and electroencephalographic changes of impending coma.
COMPLICATIONS

GASTROINTESTINAL HAEMORRHAGE AND HEPATOMA Massive haemorrhage from gastro-oesophageal varices occurred in five patients, all of whom had severely impaired liver function with defective blood coagulation; only one survived (Table I). Bleeding occurred during initial hospital treatment in three patients (Cases 2, 8, and 13), in two of whom hepatoma was found at necropsy, despite previous failure to identify malignant cells in the ascitic fluid.

OVERHYDRATION, HYPERKALAEMIA, AND AZOTAEMIA Disorders of water and electrolyte metabolism, sometimes with azotaemia, were prominent, either initially or during subsequent management (Tables I and II). Before treatment, isotope studies on 11 patients confirmed the excess total body water (TBW) and exchangeable sodium $\left(\mathrm{Na}_{E}\right)$ known to occur in patients with ascites (Birkenfeld, Liebman, O'Meara, and Edelman, 1958). Paradoxical hyponatraemia (Talso, Spafford, Ferenzi, and Jackson, 1956) was present at this stage in five patients who had serum concentrations of less than $135 \mathrm{mEq}$. of sodium per litre. Values for serum potassium $\left(K_{S}\right)$, exchangeable body potassium $\left(K_{E}\right)$, and blood urea were within the normal range, except in one patient who was hyperkalaemic and mildly azotaemic at this stage. Hyponatraemia was associated with hypochloraemia and reductions in serum bicarbonate concentrations. The lower initial values

TABLE II

CHANGES IN VALUES FOR DRY BODY WEIGHT (DBW), TOTAL BODY WATER (TBW), BODY EXCHANGEABLE SODIUM $\left(\mathrm{Na}_{E}\right)$ AND POTASSIUM $\left(\mathrm{K}_{E}\right)$, SERUM SODIUM $\left(\mathrm{Na}_{S}\right)$ AND POTASSIUM $\left(\mathrm{K}_{S}\right)$, AND BLOOD UREA (U $\left.)\right)$ BEFORE AND AFTER DIURESIS

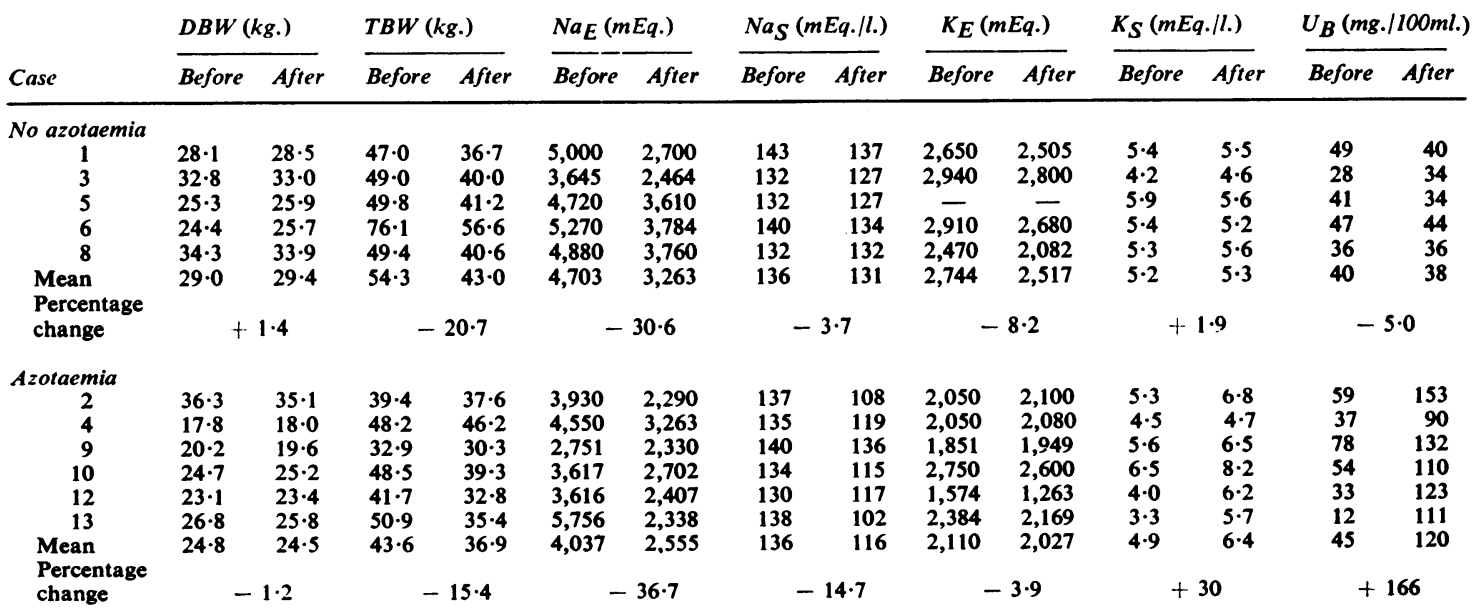


for total body water, $\mathrm{Na}_{E}$, and $\mathrm{K}_{E}$ in patients subsequently having azotaemia reflected their smaller physiques as shown by the dry body weight. Otherwise the two groups could not be distinguished before treatment.

During diuresis, greater hyponatraemia developed, while three patients became azotaemic at this stage, and three more became azotaemic during subsequent management (Table II). The presence of azotaemia was associated with symptoms, more striking metabolic changes, and a worse prognosis. The clinical syndrome consisted of apathy, nausea, and anorexia, progressing in more severe instances to personality changes and stupor. The motor system disorder of impending coma (flapping tremor, hyporeflexia, rigidity, and clonus) was not prominent. Mental changes were not specific, and abnormalities of the electroencephalogram, arterial $p \mathrm{H}$, and arterial ammonia concentrations, if present, were not striking and did not become more severe as the condition deteriorated (Summerskill et al., 1960a). Azotaemia developed in the absence of precipitating factors, such as gastrointestinal haemorrhage or paracentesis abdominis, and without evidence of pre-existing renal disease, alterations in systemic blood pressure, and volume of urine (which were recorded daily), or characteristic histological changes in the kidneys at necropsy. A smaller proportion of body water was lost by azotaemic patients than by the other patients. Losses of sodium were comparable, while relatively little potassium was lost by either group. There was much greater hyponatraemia in azotaemic patients in association with the greater water retention, but concentrations of serum potassium became raised without elevation of body potassium content $\left(\mathrm{K}_{E}\right)$. These disorders were not related to changes in flesh, as little alteration occurred in dry body weight in either group (Table II).

The patients who became azotaemic often had more severe liver disease on clinical assessment and more grossly deranged chemical tests of liver function (Table I). Two (Cases 4 and 13) recovered simultaneously with improvement in liver function, whereas azotaemia, hyponatraemia, and hyperkalaemia persisted for periods of two to nine months before death in three other patients (Cases 9, 10, and 12). Sudden death of three azotaemic patients (Cases 2, 9, and 10) appeared to be primarily due to hyperkalaemia, as electrocardiograms showed characteristic abnormalities and no alternative explanation could be found at necropsy. There was no relationship between the type or amount of drugs prescribed and the onset of azotaemia; patients subsequently having this complication had received smaller quantities of drugs and had a slower diuretic response.

Treatment of overhydration and azotaemia was unsatisfactory. Hyponatraemia without raised concentrations of serum potassium or blood urea gave rise to no specific symptoms and corrected itself spontaneously after diuresis. In azotaemic patients, overhydration was controlled temporarily by restriction of fluids, but severe thirst made this difficult for longer-term use, and azotaemia progressed notwithstanding (Cases 2, 9, 10, and 12). The enhanced water diuresis with prednisone (30 to $45 \mathrm{mg}$. daily) was not sufficient to prevent the onset or progression of overhydration and azotaemia in five patients, nor did the administration of mannitol (5\% solution) by vein cause weight loss in five patients already receiving diuretics. An increased urinary volume followed mannitol infusions but was accounted for by the fluid load administered. Four patients excreted an increased amount of sodium in the subsequent 48 hours (mean $20.5 \mathrm{mEq}$. of sodium per litre of mannitol administered).

HEPATIC COMA In addition to the neuropsychiatric changes during azotaemia, hepatic coma occurred as a terminal event following gastrointestinal haemorrhage in Cases 2, 6, and 8. Personality changes, non-specific tumour, and minor electroencephalographic abnormalities of grade 1 or 2 severity appeared to be due primarily to the severity of the liver disease on initial assessment in Cases 4, 9, 10, and 13. In Cases 1 (Fig. 2) and 7 transient impending coma was clearly related to treatment with chlorothiazide and responded quickly to withdrawal of the drug. In other cases, diuretic therapy, including chlorothiazide, had no direct influence on the neuropsychiatric changes, and three patients recovered during good diuretic responses.

Several problems associated with management during the development and course of disorders of water and electrolyte metabolism and azotaemia are illustrated by the progress in Case 10 (Fig. 3). Prolonged treatment with sodium restriction and increasing doses of diuretics were necessary to initiate diuresis. After steady loss of weight, apathy, confusion, and anorexia appeared in association with more severe hyponatraemia and hyperkalaemia, neither of which could be explained from changes in body composition as there was no increase in hydration (as indicated by the ratios $\mathrm{Na}_{E}+\mathbf{K}_{E}$ / TBW) and no evidence of sodium depletion or potassium retention from the $\mathrm{Na}_{E}$ and $\mathrm{K}_{E}$ values. The electrocardiogram showed gross changes of hyperkalaemia. Simultaneously, azotaemia developed, with deterioration in the electroencephalogram and abnormal arterial concentrations of 


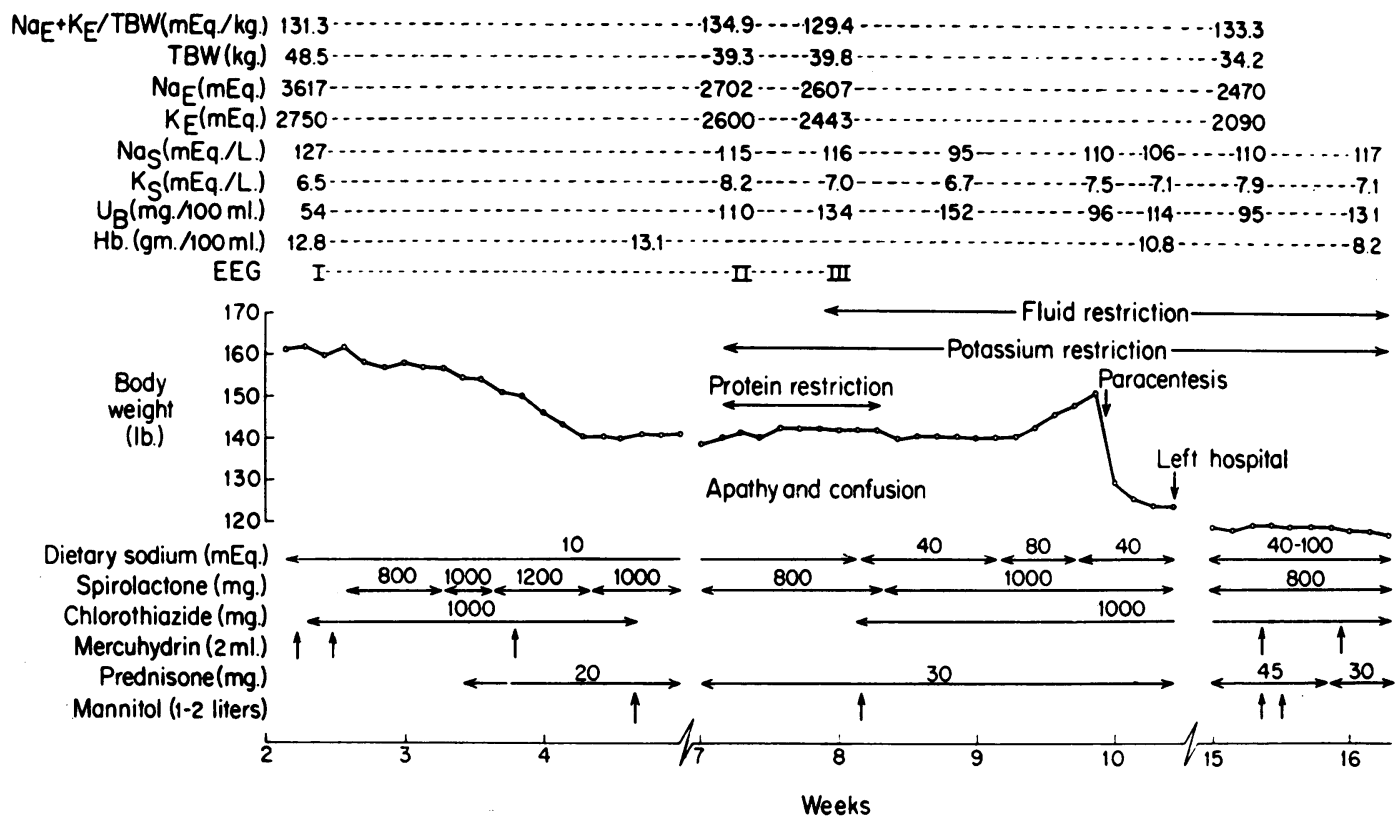

FIG. 3. Disorders of water and electrolyte metabolism and azotaemia during treatment of resistant ascites (patient 10). Changes in total body water $(T B W)$, exchangeable sodium $\left(\mathrm{Na}_{E}\right)$ and exchangeable potassium $\left(K_{E}\right)$ values; serum sodium $\left(\mathrm{Na}_{S}\right)$ and potassium $\left(K_{S}\right)$ concentrations; and haemoglobin $(H b)$ and blood urea $\left(U_{B}\right)$ concentrations, in relation to management.

ammonia, but without change in blood pressure or output of urine. The neuropsychiatric disorder was not influenced by withdrawal of protein and chlorothiazide, but restriction of potassium resulted in some improvement in serum potassium concentration and in the electrocardiographic pattern. Relative overhydration then occurred, with a fall in the ratio, $\mathrm{Na}_{E}+\mathrm{K}_{E} / \mathrm{TBW}$. Despite restriction of fluid, the concentration of serum sodium continued to fall and azotaemia increased, although improvement in the $\mathrm{Na}_{E}+\mathrm{K}_{E} / \mathrm{TBW}$ ratio occurred subsequently.

With improvement in the general condition, an increased dietary intake of sodium was attempted in conjunction with higher doses of spirolactone and chlorothiazide, so as to relax dietary restrictions before discharge from the hospital. The weight remained stable when a $40-\mathrm{mEq}$. sodium diet was used, although the concentration of serum sodium continued to fall and that of the blood urea rose, whereas an $80-\mathrm{mEq}$. sodium diet resulted in accumulation of fluid. Improvement in serum sodium and blood urea concentrations occurred, and to facilitate discharge from the hospital, paracentesis was performed uneventfully.

The further course was satisfactory only in relation to the fact that no further weight was gained. Precautions against excess intakes of water and potassium remained necessary, and serum potassium concentrations remained dangerously high, while hyponatraemia persisted and concentrations of blood urea fluctuated but never reverted to normal. On four occasions, mannitol was given without effect. Progressive anaemia occurred in association with the azotaemia; tests for occult blood in the stools had been negative on 12 occasions. There was no alteration of serum bilirubin concentration or other evidence of increased haemolysis, and blood smears, together with leucocyte and platelet counts, were unremarkable. The anaemia appeared to be associated with the impaired renal function, and blood transfusions were necessary. Longstanding constipation was aggravated by fluid restriction, and evacuation of faeces under caudal anaesthesia was necessary. Three days later the patient complained suddenly of progressive paralysis and died within five minutes, the mode of death being ascribed to hyperkalaemia, as there was no other explanation for it at post-mortem examination.

\section{COMMENT}

The long-term medical management of ascites has been emphasized less than immediate hospital treatment, although successful therapy depends particularly on perseverance with an unpalatable 
and technically difficult diet, while there is understandably little information available regarding the progress of patients when ascites is refractory to treatment. In our experience, the use of spirolactone in combination with other diuretics always overcame the initial resistance of ascites to other medical measures, although there was occasionally a delay of two weeks before diuresis began. Moreover, this treatment permitted the relaxation of dietary restriction of sodium (Clowdus et al., 1960) when necessary in subsequent management without fluid re-accumulating. The initial diuretic response was related to the number of drugs and the doses prescribed, but long-term management was achieved with less medication, the amount usually varying with the intake of sodium. Balance studies confirmed earlier observations regarding the metabolic effects of these various drugs. Spirolactone had a potassium conserving effect, whereas chlorothiazide increased the loss of potassium, and prednisone increased the excretion of water in relation to sodium and potassium (Clowdus et al., 1960; Cattan and Vesin, 1957; Dingman, Finkenstaedt, Laidlaw, Renold, Jenkins, Merrill, and Thorn, 1958; Shaldon, McLaren, and Sherlock, 1960; Laragh, Heinemann, and Demartini, 1958; Read, Laidlaw, Haslam, and Sherlock, 1959; Salassa, Mattox, and Power 1958). Nevertheless, the simultaneous administration of aldactone and chlorothiazide often led to a negative potassium balance, while the increased diuresis of water associated with prednisone therapy did not necessarily prevent overhydration. The incidence of neuropsychiatric complications attributable to chlorothiazide in these and other patients treated by us was much below that reported by Read et al. (1959), and potassium depletion was not proved to be the major factor. Concentrations of serum potassium are infrequently reliable indices of body stores of potassium in patients with ascites (Summerskill et al., 1960a; Clowdus, II, et al., 1961; Talso et $a l ., 1956)$, and the direct effect of chlorothiazide on ammonia metabolism (Owen, Flanagan, and Tyor, 1959; Mackie, Stormont, Hollister, and Davidson, 1958; Casey, Summerskill, and Orvis, 1961) seen in one of the patients reported herein was supported by the demonstration of an interrelationship between ammonia and potassium metabolism in others (Casey et al., 1961). This may explain the susceptibility of patients who had previously experienced coma to neuropsychiatric changes during chlorothiazide therapy and the raised arterial concentrations of ammonia under such circumstances, which is evident from earlier data (Read et al., 1959). These considerations were of greatest importance during periods of rapid diuresis and when complications involving water and electrolyte metabolism occurred, but they seldom influenced long-term management because of the smaller doses of drugs necessary for maintenance. A combination of spirolactone and chlorothiazide was most convenient for long-term treatment but newer drugs may have fewer disadvantages.

The constant response to a drug acting primarily as an antagonist of aldosterone indicates the importance of hyperaldosteronism in the refractoriness of ascites to standard treatment. Such resistance appeared to be closely related to the severity of the liver disease, as patients in whom liver function ultimately improved dispensed with treatment, whereas others required continued diet and therapy with diuretics. A direct relationship between hyperaldosteronism and liver function (Summerskill and Crabbé, 1957; Coppage, Island, Cooner, and Liddle, 1961) or other factors important in the formation of ascites, however, remains speculative.

Resistant ascites associated with cirrhosis carried a more favourable long-term prognosis in the alcoholic than in the non-alcoholic, as greater recovery of liver function was possible as a result of a nutritious diet and abstinence from alcohol (Summerskill, Davidson, Dible, Mallory, Sherlock, Turner, and Wolfe, 1960b). Nevertheless, relaxation of diuretic therapy and sodium restriction had to be gradual in the alcoholic. In contrast, patients with cirrhosis of uncertain cause pursued a more inexorable course (Summerskill et al., 1960b) which was reflected by their need for continued treatment to prevent re-accumulation of ascites. Only one patient became responsive after treatment to a diuretic which had been ineffective previously.

The prognosis is grave in resistant ascites because of several complications associated with advanced liver disease. Haemorrhage from ruptured gastrooesophageal varices, hepatoma, and hepatic coma occurred during the course of follow-up. Disorders of water and electrolyte metabolism of uncertain origin occurred particularly frequently and constituted perhaps the greatest problem in management. Their high incidence may support an often assumed relationship to the use of a sodium-restricted diet and diuretics. No direct connexion between the various components of treatment and these complications could be demonstrated, however, and we were particularly careful to guard against sodium or potassium depletion. Advances in the management of other complications associated with hepatic disease have resulted in the greater prominence of disorders of water and electrolyte metabolism in hepatic failure (Chalmers, 1960), and their relationship to deterioration in hepatic function appears to be most important, especially as two patients with severe hyponatraemia and 
azotaemia recovered when the liver disease improved.

Two uncertainly related phases were distinguished in this disorder, the first reflecting overhydration (Clowdus, II, et al., 1961; Birkenfeld et al., 1958; Talso et al., 1956) and the second comprising more severe overhydration in association with azotaemia and additional metabolic and clinical changes (Clowdus, II, et al., 1961). Hyponatraemia represented primarily dilution due to a relatively greater excess of body water than sodium, rather than sodium depletion; hypokalaemia, when present, may reflect the same phenomenon as well as deficiency of potassium. However, potassium supplements infrequently lead to replenishment of potassium stores as judged by changes in body potassium (Casey et al., 1961), nor were they always effective in preventing coma during treatment with chlorothiazide. In addition to sodium retention, the relative excess of body water may result from diminished free water clearance (Schedl and Bartter, 1960) or excess ADH activity (Ralli, Robson, Clarke, and Hoagland, 1945) and it was particularly prominent when azotaemia developed. Although prednisone (Dingman et al., 1958) and mannitol (Shaldon et al., 1960; Schedl and Bartter, 1960) may enhance free water clearance in some patients, there was no significant clinical effect in our azotaemic group, perhaps because sodium diuresis was already in progress. Restriction of fluids limited overhydration most effectively but failed to halt azotaemia and caused great thirst.

Despite overhydration and consequent dilution, hyperkalaemia occurred with azotaemia and appeared important as a cause of death. It could not be related to retention of potassium, thus raising the possibility that redistribution of potassium from the intracellular to the extracellular compartments resulted in hyperkalaemia and contributed to hyponatraemia. Potassium restriction was not fully effective, and the use of insulin, glucose, and sorbitol in the treatment of hyperkalaemia must be considered also.

The impairment of renal function leading to azotaemia in our cases occurred without clinical or histological evidence of renal disease. A disorder of the renal circulation has been inferred by Papper, Belsky, and Bleifer (1959) and Hecker and Sherlock (1956), although oliguria and hypotension were not invariably present in their patients. In our cases, azotaemia preceded detectable oliguria and peripheral vascular collapse, but renal plasma flow was low (Feichter, Summerskill, and Wakim, unpublished data), as in three cases reported by Papper et al. (1959). This appeared the most important cause of a diminished glomerular filtration rate, but the anatomical and pathological basis is conjectural. The occurrence of progressive anaemia in one azotaemic patient was of interest in view of the relationships between erythropoiesis and renal function. The poor immediate prognosis of severe hyponatraemia with azotaemia stressed by others (Papper et al., 1959; Hecker and Sherlock, 1956) was not altogether supported in our group, as these changes sometimes persisted for weeks or months and two patients recovered.

Secondary impairment of renal function may modify the clinical picture. The neuropsychiatric changes in azotaemic patients were not characteristic of hepatic coma and did not respond strikingly to restriction of protein and antibiotics. Abnormalities of the electroencephalogram, arterial $p \mathrm{H}$, and blood ammonia concentration may be influenced by disorders of water and electrolyte metabolism and azotaemia (Chalmers, 1960; Webster and Gabuzda, 1959), thus making separation of clinical patterns difficult in patients with severe liver disease.

Our patients had hepatic disease of a severity which precluded initial consideration of surgical treatment and militated against the successful medical or surgical management of any subsequent gastrointestinal haemorrhage. The therapeutic approach of choice to resistant ascites, therefore, must be evaluated in relation to improvements in conservative management, as well as in surgical techniques and results (McDermott, 1960; Welch, Welch, and Carter, 1959; Barker and Reemtsma, 1960). The simultaneous improvement in liver function and portal hypertension (Reynolds, Geller, Kuzma, and Redeker, 1960) in cirrhosis of the alcoholic suggests that operation may be deferred for six months, so that response to medical treatment and the sincerity of abstention from alcohol can be assessed. Post-operative improvement in ascites may on occasion be related to abstinence from alcohol rather than to the operation itself, whereas hazardous operations are seldom warranted when continued alcoholism leads to hepatic failure. Until the various factors responsible for resistance of ascites in different patients are more clearly defined, surgical treatment would appear to be most clearly indicated for the relatively uncommon patient in whom resistant ascites is associated with apparently good liver function, the latter being judged particularly by general nutrition, the absence of jaundice or previous coma, and satisfactory blood coagulation. The demonstration of gastro-oesophageal varices would favour a portal-systemic shunt, particularly if gastrointestinal haemorrhage had occurred previously, whereas adrenalectomy might be considered for the other patients. In regard to paracentesis, Copland (1844-58) commented a century ago that it 'seems calculated to increase the mischief, and to 
diminish the chances of a complete cure. It is the last means to which recourse should be had'.

\section{SUMMARY}

Resistance of ascites associated with hepatic cirrhosis to standard treatment was demonstrated in 13 patients, all of whom responded to treatment in a hospital with dietary restriction of sodium and a combination of diuretic agents, which included spirolactone. The effects of various combinations of drugs on excretion of water, sodium, and potassium were studied. Medical supervision and treatment were continued for periods of up to two years, and the following patterns of response in relation to the long-term management of resistant ascites were found.

Patients in whom alcoholism had been a factor in the previous six months were ultimately able to dispense with treatment, but only after several months. This was associated with continued abstention from alcohol and slow improvement in liver function. In patients with cirrhosis of uncertain cause, liver function either deteriorated or remained unchanged, and continuous or intermittent treatment was necessary. The amount of drugs required depended on patients' ability to adhere to a low-sodium diet. In most instances, it was necessary to relax the degree of sodium restriction. Continuous treatment with spirolactone and other drugs permitted a more liberal intake of sodium when necessary. The details and complications of management are described with particular emphasis on those involving water and electrolyte metabolism.

Six patients have remained well and free from disabling ascites, and six have died from complications associated with progressive liver disease; one patient died from an unrelated cause. Now that it is feasible to treat resistant ascites for long periods on an out-patient basis with a medical programme, the management of this condition, especially in regard to surgical procedures, is re-evaluated.

\section{REFERENCES}

Barker, H. G., and Reemtsma, K. (1960). The portacaval shunt operation in patients with cirrhosis and ascites. Surgery, 48, 142-152.

Birkenfeld, L. W., Leibman, J., O'Meara, M. P., and Edelman, I. S. (1958). Total exchangeable sodium, total exchangeable potassium, and total body water in edematous patients with cirrhosis of the liver and congestive heart failure. J. clin. Invest., 37, 687-698.

Blakemore, A. H. (1952). Portacaval shunting for portal hypertension. Surg. Gynec. Obstet., 94, 443-454.

Casey, T. H., Summerskill, W. H. I., and Orvis, A. L. (1961). Disorders of potassium metabolism in liver disease. (Abstr.) J. clin. Invest., 40, 1028-1029.

Cattan, R., and Vesin, P. (1957). Etat actuel du traitement des cirrhoses ascitiques par la delta-cortisone. Sem. Hôp. Paris, $33,76-79$.
Chalmers, T. C. (1960). Pathogenesis and treatment of hepatic failure. New Engl. J. Med., 363, 23-30; 77-82.

Clowdus, B. F., Higgins, J. A., Rosevear, J. W., and Summerskill, W. H. J. (1960). Treatment of 'refractory' ascites with a new aldosterone antagonist in patients with cirrhosis. Proc. Mayo Clin., 35, 97-105.

-, II, Summerskill, W. H. J., Casey, T. H., Higgins, J. A., and Orvis, A. L. (1961). Isotope studies of the development of water and electrolyte disorders and azotaemia during the treatment of ascites. Gastroenterology, 41, 360-370.

Copland, James (1844-58). A Dictionary of Practical Medicine. Longman, Brown. Green, Longmans and Roberts, London.

Coppage, W. S., Island, D., Cooner, A. E., and Liddle, G. W. (1961). Metabolism of aldosterone in normal subjects and patients with cirrhosis (Abstr.) Clin. Res., 9, 177.

Dingman, J. F., Finkenstaedt, J. T., Laidlaw, J. C., Renold, A. E., Jenkins, D., Merrill, J. P., and Thorn, G. W. (1958). Influence of intravenously administered adrenal steroids on sodium and water excretion in normal and Addisonian subjects. Metabolism, 7, 608-623.

Feichter, R. A., Summerskill, W. H. J., and Wakim, K. G. Unpublished data.

Giuseffi, J., Werk, E. E., Jr., Larson, P. U., Shiff, L., and Elliott, D. W. (1957). Effect of bilateral adrenalectomy in a patient with massive ascites and postnecrotic cirrhosis. New Engl. J. Med., 257, 796-803.

Hecker, R., and Sherlock, Sheila (1956). Electrolyte and circulatory changes in terminal liver failure. Lancet, 2, 1121-1125.

Henley, K. S., Streeten, D. H. P., and Pollard, H. M. (1960). Hyperaldosteronism in liver disease: The treatment of refractory ascites by adrenalectomy and by the administration of spirolactones. Gastroenterology, 38, 681-689.

Kagawa, C. M., Cella, J. A., and van Arman, C. G. (1957). Action of new steroids in blocking effects of aldosterone and deoxycorticosterone on salt. Science, 126, 1015-1016.

Laragh, J. H., Heinemann, H. O., and Demartini, F. E. (1958). Effect of chlorothiazide on electrolyte transport in man: Its use in the treatment of edema of congestive heart failure, nephrosis, and cirrhosis. J. Amer. med. Ass., 166, 145-152.

Liddle, G. W. (1958). Aldosterone antagonists. A.M.A. Arch. intern. Med., 102, 998-1004.

Linton, R. R. (1956). Portal hypertension. In Schiff, Leon: Diseases of the Liver, pp. 195-233. Lippincott, Philadelphia.

Luetscher, J. A., Jr., and Johnson, B. B. (1954). Observations on the sodium-retaining corticoid (aldosterone) in the urine of children and adults in relation to sodium balance and edema. J. clin. Invest., 33, 1441-1446.

Mackby, M. J. (1960). Techniques of portal decompression. Int. Abstr, Surg, 110, 521-526.

Mackie, J. E., Stormont, J. M., Hollister, R. M., and Davidson, C. S. (1958). Production of impending hepatic coma by chlorothiazide and its prevention by antibiotics. New Engl. J. Med., 259, 1151-1156.

Marson, F. G. W. (1954). Total adrenalectomy in hepatic cirrhosis with ascites. Lancet, $2,847-848$.

McDermott, W. V., Jr. (1960). The double portacaval shunt in the treatment of cirrhotic ascites. Surg. Gynec. Obstet., 110, 457-469.

Owen, E. E., Flanagan, J. F., and Tyor, M. P. (1959). Kidney as a source of blood ammonia: Effect of chlorothiazide. Proc. Soc. exp. Biol. (N.Y.), 102, 696-697.

Papper, S., Belsky, J. L., and Bleifer, K. H. (1959). Renal failure in Laennec's cirrhosis of the liver. I. Description of clinical and laboratory features. Ann. intern. Med., 51, 759-773.

Ralli, Elaine P., Robson, J. S., Clarke, Delphine, and Hoagland, C. L. (1945). Factors influencing ascites in patients with cirrhosis of the liver. J. clin. Invest., 24, 316-325.

Ratnoff, O. D., and Patek, A. J., Jr. (1942). The natural history of Laennec's cirrhosis of the liver. Medicine (Baltimore), 21, 207-268.

Read, A. E., Laidlaw, J., Haslam, R. M., and Sherlock, Sheila (1959). Neuropsychiatric complications following chlorothiazide therapy in patients with hepatic cirrhosis: Possible relation to hypokalaemia. Clin. Sci., 18, 409-423.

Reynolds, T. B., Geller, H. M., Kuzma, O. T., and Redeker, A. G. (1960). Spontaneous decrease in portal pressure with clinical improvement in cirrhosis. New Engl. J. Med., 263, 734-739.

Salassa, R. M., Mattox, V. R., and Power, M. H. (1958). Effect of an aldosterone antagonist on sodium and potassium excretion in primary hyperaldosteronism. (Letter to the Editor.) J. clin. Endocr., 18, 787-789. 
Schedl, H. P., and Bartter, F. C. (1960). An explanation for and experimental correction of the abnormal water diuresis in cirrhosis. J. clin. Invest., 39, 248-261.

Seligson, David, and Hirahara, Katsugi. (1957). The measurement of ammonia in whole blood, erythrocytes, and plasma. J. Lab. clin. Med., 49, 962-974.

Shaldon, S., McLaren, J. R., and Sherlock, S. (1960). Resistant ascites treated by combined diuretic therapy (spironolactone, mannitol, and chlorothiazide). Lancet, 1, 609-613.

Sherlock, Sheila (1958). Diseases of the Liver and Biliary System, 2nd ed. Blackwell, Oxford.

Stormont, J. M., Crabbś, J., Fast, B. Wolfe, S. J., and Davidson, C. S. (1959). The effect of prednisone and amphenone on fluid and electrolyte balance and on aldosterone excretion of patients with cirrhosis and ascites. J.Lab.clin. Med.,53,396-416.

Summerskill, W. H. J., and Crabbé, J. (1957). Effect of amphenone therapy on urinary excretion of aldosterone and sodium in hepatic cirrhosis with ascites. Lancet, 2, 1091-1095.
_- Clowdus, B. F., and Casey, T. H. (1960a). Clinical and metabolic changes during the development of azotemia in hepatic failure with ascites. Proc. Mayo Clin., 35, 783-791.

—, Davidson, C. S., Dible, J. H., Mallory, G. K., Sherlock, S., Turner, M. D., and Wolfe, S. J. (1960b). Cirrhosis of the liver: A study of alcoholic and non-alcoholic patients in Boston and London. New Engl. J. Med., 262, 1-9.

Talso, P. J., Spafford, Norma, Ferenzi, G., and Jackson, Helen O. (1956). Paradoxical hyponatremia associated with congestive heart failure and with cirrhosis of the liver. Metabolism, 5, 58-69.

Walker, R. M. (1957). Portacaval anastomosis. Lancet, 1, 57-59.

Webster, L. T., Jr., and Gabuzda, G. J. (1959). Relation of azotemia to blood "ammonium" in patients with hepatic cirrhosis. A.M.A. Arch. intern. Med., 103, 15-22.

Welch, C. S., Welch, H. F., and Carter, J. H. (1959). The treatment of ascites by side to side portacaval shunt. Ann. Surg., 150. 428-440. 